\title{
An Assessment of Financial Reporting and Auditing Practices in County Governments of Kenya
}

\author{
Peter Rigii Gaitho \\ School of Business, University of Nairobi, Kenya
}

\begin{abstract}
Received: Sep. 27, 2018 Accepted: Oct. 24, 2018 Online published: Oct. 31, 2018
doi:10.5296/jpag.v8i4.13707ＵRL: https://doi.org/10.5296/jpag.v8i4.13707
\end{abstract}

\begin{abstract}
This paper assesses the financial reporting and auditing practices in the County Governments in Kenya. The paper reviews available literature on financial reporting and auditing practices in the Counties. The paper finds weak financial and auditing practices as decried in the Auditor General's reports since the county governments became operational in 2013. It emerged that the counties kept incomplete financial reports which did not reflect the true financial positions of the counties and were unreliable for proper auditing. The paper recommends the need for county leadership to hire qualified finance and accounting staff to ensure proper financial reporting and auditing in the counties. The paper also recommends the need to strengthen the sanction enforcement mechanism for those found to be involved in financial malpractices. The paper suggests the adoption of new media channels such as Facebook and Twitter in disseminating as well as discussing the financial and audit reports.
\end{abstract}

Keywords: accountability, financial reporting, auditing, county governments

\section{Introduction}

Financial reporting and auditing have been identified as key components necessary for accountability in private sector as well as public entities. These two components have also been identified as key cogs in public financial management and service delivery in decentralized units such as county governments (Scott, 2018; Maina, 2016). Financial reporting are statements including balance sheet, cash flow statement, stakeholders' statement of equity with formal records of a person, business, or an entity's monetary activities and position. In Latin America, most states have adopted IPSASs (International Public Sector Accounting Standards) to improve government financial reporting practices (Montesinos, Brusca \& Go'mez-Villegas, 2016). Similarly, the United Kingdom's government has occasionally initiated reforms for financial better financial reporting in local governments to improve service delivery (Ferry \& Eckersley, 2015).

One of the greatest challenges towards achieving accountability in public entities has been 
associated with lack of proper financial reporting and auditing practices. In Kenya, Article 201 of the Kenyan constitution lists good governance, transparency, integrity and accountability as principles and values of public finance for any public office (Mwenda, 2010). Today, accountability has become a critical issue in Kenya's public domain more so with devolution. The importance of public accountability is to enhance the integrity of public office holders and ensuring that public resources are put to good use. Nevertheless, recent corruption reports in Kenya County Governments have raised the question of the county's leadership and employees' fidelity to accountability. The office of the Auditor General's reports indicate improper County Governments' financial control systems that have resulted to misuse of public funds. For instance, Busia County Assembly is alleged to have paid five contractors Kshs. 10.7 million for public sensitization on one bill (Kibet, 2017). This paper provides an insight into the nature of Kenyan County Governments' financial reporting and auditing practices.

\section{Financial Reporting Practices}

Financial reporting practices are critical pillars for enhancing transparency and accountability in corporate or institutional governance and accounting principles and practices. Samani (2015) resonates that the demand for financial reporting is influenced by increased obligations for transparency on the conflict interests and information asymmetries between contracting parties. Further, he illustrates that demand for accounting info within contractual relationships projects from the confines of pertinent information in the monitoring of managerial behaviours that are fundamental for the contractual efficiencies. The Financial Reporting Council (FRC) opine that auditing is tasked "to provide assurance to shareholders regarding the financial reports produced by the management of the companies in which they hold shares" (The Financial Reporting Council, 2015). However, other stakeholders such as lenders, suppliers and customers, as well as ratings agencies and the general public, also benefit from the assurance audit firms provide.

In a national comparative research addressing monetary domains by Harrison and Sayogo (2014) explored correlations between political, socio-cultural, economic, and government's concepts and conditions vital for open governance defined as transparency in budgeting, processes, and information accountability. The duo revealed there was a relationship between the involvement of auditing authorities, accountability, and transparency and human capital, democracy, and budgeting documentations' disclosures to the public.

Several authors (including Carlin, 2005; Paulsson, 2006; Ellwood \& Newberry, 2007) have analysed the move to adopt accrual based accounting and financial reporting in the public sector entities from cash accounting which has been in use for decades. Ellwood and Newberry (2007) argue that the accrual accounting and reporting is a political tool intended to push contentious neoliberal policies and political agendas such as privatization and trade liberalisation by providing misleading information.

Another issue which has dominated financial reporting literature has been the adoption of International Public Sector Accounting Standards (IPSAS) by developing countries mainly due to pressure from international agencies such as International Public Sector Accounting 
Standards Board (IPSASB) and the World Bank (Senarath \& Ukwatte, 2015). Ijeoma (2014) found that the adoption of IPSAS enhanced credibility, integrity and reliability of the State's financial reporting in Nigerian public sector. Ijeoma also found that IPAS enable effective internal control in addition to a result oriented financial framework in Nigeria's public sector thus better service delivery on its services more efficiently and effectively.

\section{Auditing Practices}

Auditing has been defined as a systematic, independent and objective examination of data, statements, records, operations and projects in a bid to verify and confirm their status. This examination relates to financial and non-financial elements of the issues being queried (Siswana, 2007; McKenna, 2011). Jordaan (2013) notes that based on the evidence collected by the auditor he the proceeds to make a judgement based on such evidence and the propositions he had formulated with regard to the issue being audited.

Liu and Lin (2012) have noted that auditing is critical in the public sector financial management in checking on fraud, waste and misappropriation of funds. Auditing is also necessarily to ensure the truthfulness and reliability of financial reports prepared by the public entities such as county governments. Ferry and Eckersley (2015) found that the Central Government's lack of standardized and rigorous audit systems resulted to the general weakening of the local systems of accountability. Lessmann and Markwardt (2010) have specifically the need for auditing to monitor effectiveness of revenue collection by local governments.

James (2003) argues that auditors are very important in guaranteeing the quality and reliability of financial reports prepared by entities and thus ensuring accountability and proper corporate governance practices. Asare (2009) further note that internal auditors are the first defence line in ensuring the reliability of financial reports by flagging off fraudulent activities. However, Gras-Gil, Marin-Hernandez and Garcia-Perez (2012) have argued that the cooperation and coordination between the internal and external auditors is necessary for quality and reliable financial reporting. The core competencies distinguishing internal auditors and external auditors are their deeper understanding the financial and operational aspects of an entity.

According to Asare (2009), auditing in the public sector is faced with the challenge of compliance to rules and regulations. The Institute of Certified Public Accountants of Kenya (ICPAK) notes that there have been reforms aimed at harmonising and facilitating the work of auditors in the public sector across Africa, despite lack of political goodwill (Oluoch, 2017).

\section{Methodology}

The paper adopted a qualitative research design in assessing the nature of financial reporting and auditing practices in the County Governments of Kenya. In explaining the importance of qualitative research design in management studies, Llewellyn (1999) had noted that convincing narration as a thought and persuasion process was as valid as use of calculations prevalent in quantitative research design. Gummesson (2006) emphasizes that qualitative research allows researchers to deal with complex situations with many actors and vested 
interests as the issues regarding financial reporting and auditing in the County Governments in Kenya, a phenomenon where conventional statistical methods are likely to yield unconvincing results.

Specifically, the research relied on scholarly journals, the Kenyan Constitution, County policy documentations, Auditor General's report, Media reports and news stories on Counties such as corruption, spending, investments, employments and County and independent state Corporations' websites, and the Google search engine to make its deductions.

Keywords Employed in the search included 'accountability by Kenya County Governments' 'Auditor Generals reports on Counties' 'financial reporting and budgeting in Kenya'. A further refinement of the study was attained by application of either of the 47 counties' names. A thematic approach was also used to sort out issues developing from the review's analysis. The paper then used thematic analysis to analyse and arrange the information obtained.

\section{Findings and Discussion}

The study depended on online searches and documents to get insight on the financial reporting and auditing practices among the 47 county governments of Kenya. The findings are discussed under two sections. The first section discusses issues emerging with regard to financial reporting practices in the County Governments of Kenya. The second section evaluates findings concerning airing practices.

\section{Financial Reporting Practices in the Counties}

The accounting and financial reporting in the counties have their basis in Article 226 of the Constitution of Kenya which mandated parliament to enact laws to guide the practices. Public Finance Management (2015) was thus enacted replacing The PFMA of 2012. The Act provides that all of the 47 Kenyan Counties to publish all the info related to the County's budgeting cycle from formulation, approval, implementation to auditing (Were, 2017).

The Auditor General reports have extensively detailed the nature of financial reporting in the counties in Kenya. Auditor General reports released in 2016 revealed rampant misuse of public resources as a result of weak financial controls and failure to properly account for spent funds by county assemblies. For instance, with regards to Baringo County, the Auditor showed some lapse in the following misappropriation of resources; the construction of county assemblies' cafeteria was reported to have cost Kshs 17 Million; a contract to Supply of kitchen equipment was awarded two different companies at Kshs 309,000 and Kshs 348,075 respectively. The County also reported an expense of Ksh 20,000 for a wooden meat chop board and Kshs 54,000 for a pot stacking rack, though they were fabricated in a local workshop within the county (Auditor General, 2016b).

In the case of Busia County the Auditor General (2016a) finds lapses in financial reporting where he highlights some weaknesses in financial reporting, especially on proper record keeping. Auditor general highlighted that the county reported that Kshs 10.7 million was paid to five firms to sensitize the public on five similar bills. The report further showed that the county assembly failed to provide relevant documents in support of Kshs 16.7 million travel 
and subsistence allowances (Auditor General, 2016a). This is against the generally accepted rules in financial reporting which require that an organization should keep sufficient records to show and explains all transactions (OECD, 2013). The Auditor General (2016e) found weaknesses in the financial reporting about the Elgeyo Marakwet County Assembly spending amounting to Kshs 6.8 million for furniture and equipment as it was not indicated that at the time of reporting the building where they were to be installed was still under constructions. This indicated inappropriate reporting since it is only prudent to purchase furniture after the building where they are to be premised is completed.

In the case of Embu County, the Auditor General (2016f) found similar weaknesses. He highlighted that Embu County assembly reported an expense twice. This was an amount of Kshs 120,000 for an education committee conference to Izaac Walton yet the same committed was at Nairobi Utalii during the same period. Once could only conclude misappropriation since a committee cannot seat in two different location at the same time for the same purpose. The report further showed that Embu County reported an expense of Kshs 7.6 million for foreign trips to Tanzania and China for MCAs' training in advanced financial and human resource managed, yet the actual training was conducted locally, at Eastern and Southern Africa Management Institute. The paper noted that the course was not even related to their core mandate as MCAs (Auditor General, 2016f).

The Auditor General (2016g) also found lapses in financial reporting in Lamu County and Kiambu County. In Kiambu County, the report revealed that the County Assembly organized three workshops that Cost Kshs 35million without supporting documents to justify the expenditure (Auditor General, 2016g). In Lamu County, the county assembles spent Ksh 10 million on freight to abroad for training that could have been done locally (Auditor General, 2016k).

These challenges are reported every financial year and affect almost all counties. The Auditor General reports on weaknesses of financial reporting practices agree with one highlighted by Ernst and Young (2015). They noted that the County Governments use unreliable/manual systems which make it difficult to ascertain completeness of revenues, for instance, parting revenue. Majority of the Counties lack the capacity to handle the financial complexity due to inadequate skills and inadequate staff. This is against the requirements as articulated in The Strategy for PFM Reforms in Kenya, that for any county to achieve effective public finance management, they should build and maintain competent staff including but not limited to auditors and accountants who can sustain financial management reforms at various levels of government (Rotich, 2016).

Frequent transfers of key accounting officers such as treasurers and clerks are also a challenge that has affected financial reporting by the County Governments in Kenya (Ernst and Young, 2015). Further, Ernst and Young (2015) report on auditing local and county governments highlighted that political interference, the weak governance structure for financial reporting and controls; as well as inappropriate historical culture for financial reporting as some of the challenges that affect financial reporting in Country Governments. Political interferences are perhaps the major hindrance to auditor general's operation in 
Counties and failure to implement his recommendations, evidenced by recurrence of same mistakes in reporting.

Based on the Auditor General reports other oversight bodies investigations such as the senate have shown the extent of the poor and weak accounting and financial reporting by the county governments. On follow up regarding reported errors and inaccuracies in the financial statements submitted by Kwale County for the 2013/2014 financial year, the Senate in 2018 was still pursuing the matter showing the intricacies of financial reporting in the counties (Njoki, 2018).

\section{Auditing Practices in the Counties}

As is the case with financial reporting auditing in the counties is also rooted in Article 226 of the Constitution which mandates the Auditor General to examine the counties' financial records. In the spirit of accountability, auditing practices are aimed at examining the complacency of institutional processes and financial activities based on external and internal requirements. Under Sect 155 (1) of the PFMA, County Governments are authorized to establish an internal auditing system that will assist in enabling a systematic approach of evaluating and improving the efficiency of risk control, management, and governance processes. The Act also provides for the establishment of County Auditing Committee as independent expert to support with assessment of Counties' complacency to PFM regulations, and support Accounting Officers on their responsibilities in issues of risk governance and control and associated assurance.

The Auditing committee is enshrined to present to the County's Executive Committee reports of deliberations and resolutions and annual county fiscal reports. Similarly, the auditing committee ensures the adherence to recommendation from external audits from the Auditor General or other independent bodies (The Kenya Gazette, 2016).

Poor Financial reporting practices in County Government in Kenya is an indication that the internal audit department does not operate effectively. Good auditing practices require that the internal audit department establish efficient financial control and internal control systems. Most of the County Governments lack adequate financial controls. According to Brennan and Soloman (2008), financial controls are the measures established by an organization to ensure attainment of the entity's objectives, goals, and missions. They are systems of policies and procedures that protect the assets of an organization, create reliable financial reporting, promote compliance with laws and regulations as well as achieve effective and efficient operations (Chemeltorit, Namusonge \& Wandera, 2016)

Besides, accounting and reporting, financial control systems also help in the communication process, both externally and internally. I comprise procedures for handling funds received and expended by the county. The system also helps in preparation of appropriate and timely financial reports to the county executive, executing annual audits of the financial statement of the County as well as maintaining inventory records of Assets (Chemeltorit et al. 2016). This is lacking in most of the County Government. For instance, a study conducted in Nakuru County, Wang'ombe and Kibati (2016) revealed that the county has fluidity in the financial 
control systems especially in capturing transaction accurately. This is a clear indication of some loopholes that could be used to divert county resources.

Another indicator that the audit department of most county Governments has failed is lack of effective internal control systems. Internal controls refer to processes designed to provide reasonable assurance about the achievement of a certain entity concerning the reliability of financial reporting, efficiency and effectiveness of operations as well as compliance with relevant applicable laws and regulations (Chemeltorit et al. 2016). Lack of appropriate internal controls is evidenced by numerous errors the counties are making in their financial reporting. For instance, the Auditors Generals report of 2015/2016 revealed that 24 counties could not account for Kshs 150 billion (Kamau, 2016). This shows a serious book-keeping and auditing failure at the devolved governments level.

The Auditor General's report showed that Nairobi County was unable to account for Kshs 20 billion (Auditor General, 2016h). The auditor could not confirm the accuracy of a receipt of Kshs 4 billion in Vihiga County. Vihiga County could not explain the reason they had opened 52 bank accounts (Auditor General, 2016j). In Nyeri County, the auditor found that there was an unexplained difference of Kshs 162 million in the statement of receipts and payments. In the same county, Ksh 2.3 billion was not supported with appropriate schedules or ledgers; hence unable to tell whether the amount of spend within in a lawful manner (Auditor General, 2016j). In Murang'a County, Kshs 5.2 Billion was not appropriated supported with documents (Auditor General, 2016g).

The Auditor General could not give an opinion about the financial reports of the 24 counties as a result of numerous errors and missing information that rendered him unable finishes his audit (Kamau, 2016). However, the auditor general gave an adverse opinion, the worst opinion an institution can get from an auditor to Kirinyaga and Kakamega counties (Auditor General, 2016c; 2016d). An adverse report shows that the auditor lack confidence in the financial health of an entity based on the report they presented. This could mean that the accountants and auditors in those counties were not qualified and experienced with the nature of their work. This can be attributed to the variances in the financial statements, inaccuracy and incompleteness found in the Kakamega and Kirinyaga counties financial reports by the auditor general qualified.

\section{Conclusion}

The paper found that financial reporting function at the county governments in Kenya are a statutory requirement which are necessary to produce statements from the accounting information for use by oversight bodies including County Assembly, Office of Controller of Budgets (OCOB), Commission for Revenue Allocation (CRA), the Kenya National Audit Office (KENAO), donors and the public. institution's financial status to investors, the management, and Government.

The paper found weak financial reporting and auditing practices as decried in the Auditor General's reports since the county governments became operational in 2013. The paper found that this was not an isolated case in few counties but was the norm since their 
operationalization in 2013. According the reviewed Auditor General reports, the major setback for counties in financial reporting has been hiring of unqualified staff to undertake financial and accounting roles. The findings are in agreement with Ringa (2017) who found that majority of county accounting officers had limited knowledge and experience in managing public funds. Gaitho (2018), had found that the hiring processes in the Kenyan county governments was fraught with malpractices such as nepotism and favoritism. The paper findings agreed with Cooker and Adams (2012) who had linked poor financial accounting and reporting at local governments to staff ethics and capacity to undertake proper financial management roles. Further, the paper findings are also in agreement with Ruppel (2018) who argued that government entities financial reports do not provide any real insight into their financial position or performance.

\section{Recommendations}

There is need for the County executive led by the Governor to ensure that qualified and experienced staff to run the accounting and finance departments of the counties. The executive should also ensure that those charged with financial reporting and auditing the Counties' are facilitated and provided with the required information they require to prepare reliable financial reports. The county leadership also need to put in place mechanisms through which to share and discuss with the public and other stakeholders the financial reports as well as the audit reports.

The County Assembly needs to diligently perform its rightful oversight role in the county affairs by hiring qualified teams to assist the county assembly members in technical matters related to accounting and financial reporting practices. The National Assembly also needs to allocate adequate financial budget allocation to the Office of the Auditor General to enable hiring of adequate staff to ensure timely auditing of the counties.

The paper also recommends that the oversight bodies such as the Auditor General's Office, Ethics and Anti Corruption Commission, Assets Recovery Agency, Financial Reporting Centre, The Senate and the County Assemblies to strengthen the sanctions enforcement mechanisms to ensure those found to engage in financial reporting malpractices can be punished.

The civil society organizations also need to present the financial and audit reports concerning the counties in user friendly formats which are understandable to the public. The civil society also need to promote use of new communication channels such as WhatsApp, Facebook and Twitter to disseminate their take on these financial and auditing practices in the counties.

\section{References}

Asare, T. (2009). Internal auditing in the public sector: Promoting good governance and performance improvement. International Journal on Governmental Financial Management, 9(1), 15-28.

Auditor General (2016a). Auditor General Report of the Auditor-General on the Financial Statements of Busia County Government for the Period Ended 30 June 2016. Nairobi: 
Auditor

General's

Office.

Available

at

www.oagkenya.go.ke/index.php/reports/doc_download/1445-busia-ce

Auditor General (2016b). Auditor General Report of the Auditor-General on the Financial Statements of Baringo County Government for the Period Ended 30 June 2016. Nairobi: Auditor General's

Office.

Available

at

www.oagkenya.go.ke/index.php/reports/doc_download/1440-baringo-ce

Auditor General (2016c). Auditor General Report of the Auditor-General on the Financial Statements of Kirinyaga County Government for the Period Ended 30 June 2016. Nairobi: Auditor General's

Office. Available

at www.oagkenya.go.ke/index.php/reports/doc_download/1489-kirinyaga-ca

Auditor General (2016d). Auditor General Report of the Auditor-General on the Financial Statements of Kakamega County Government for the Period Ended 30 June 2016. Nairobi: Auditor General's Office. Available at www.oagkenya.go.ke/index.php/reports/doc_download/1470-kakamega-ca

Auditor General (2016e). Auditor General Report of the Auditor-General on the Financial Statements of Elgeyo Marakwet County Government for the Period Ended 30 June 2016.Nairobi: Auditor General's Office. Available at www.oagkenya.go.ke/index.php/reports/doc_download/1469-elgeyo-marakwet-ce

Auditor General (2016f). Auditor General Report of the Auditor-General on the Financial Statements of Embu County Government for the Period Ended 30 June 2016. Nairobi: Auditor General's Office. Available at www.oagkenya.go.ke/index.php/reports/doc_download/1481-embu-ca

Auditor General (2016g). Auditor General Report of the Auditor-General on the Financial Statements of Kiambu County Government for the Period Ended 30 June 2016. Nairobi: Auditor General's Office. Available at www.oagkenya.go.ke/index.php/reports/doc_download/1450-kiambu-ca

Auditor General (2016h). Auditor General Report of the Auditor-General on the Financial Statements of Nairobi County Government for the Period Ended 30 June 2016. Nairobi: Auditor General's Office. Available at www.oagkenya.go.ke/index.php/reports/doc_download/1513-nairobi-city-ce

Auditor General (2016i). Auditor General Report of the Auditor-General on the Financial Statements of Murang'a County Government for the Period Ended 30 June 2016. Nairobi: Auditor General's Office. Available at www.oagkenya.go.ke/index.php/reports/doc_download/1474-muranga-ca

Auditor General (2016j). Auditor General Report of the Auditor-General on the Financial Statements of Vihiga County Government for the Period Ended 30 June 2016. Nairobi: Auditor General's Office. Available at www.oagkenya.go.ke/index.php/reports/doc_download/1529-vihiga-ce 
Auditor General (2016k). Auditor General Report of the Auditor-General on the Financial Statements of Lamu County Government for the Period Ended 30 June 2016. Nairobi: Auditor General's Office. Available at www.oagkenya.go.ke/index.php/reports/doc_download/708-lamu-cg

Auditor General. (2015). Auditor General Report of the Auditor-General on the Financial Statements of Nakuru County Government for the Sixteen (16) Months Period Ended 30 June 2014. Nairobi: Auditor General's Office. Available at:

Brennan, N. M., \& Solomon, J. (2008). Corporate governance, accountability and mechanisms of accountability: an overview. Accounting, Auditing \& Accountability Journal, 21(7), 885-906. https://doi.org/10.1108/09513570810907401

Carlin, T. M. (2005). Debating the impact of accrual accounting and reporting in the public sector. Financial Accountability \& Management, 21(3), 309-336. https://doi.org/10.1111/j.0267-4424.2005.00223.x

Chemeltorit, S. M., Namusonge, \&Wandera, R. (2016). An Assessment of Factors for Financial Control on Performance of West Pokot County Government. International Journal of Social Science and Humanities Research, 4(4), 43-50. Available at www.researchpublish.com

Ellwood, S., \& Newberry, S. (2007). Public sector accrual accounting: institutionalising neo-liberal principles? Accounting, Auditing \& Accountability Journal, 20(4), 549-573.

Ernst \& Young. (2015). Auditing the Local and County Governments: A Case for Outsourcing. Nairobi: Ernst \& Young. Available at https://www.icpak.com/wp-content/uploads/2015/09/Auditing-the-Counties-and-Local-Gover nments.pdf

Ferry, L., \& Eckersley, P. (2015). Budgeting and governing for deficit reduction in the UK public sector: Act three 'accountability and audit arrangements'. Public Money \& Management, 35(3), 203-210. https://doi.org/10.1080/09540962.2015.1027496

Gaitho, P. R. (2018). Implication of Administrative Structures and Appointment Practices on Service Delivery in County Governments of Kenya. Researchjournali's Journal of Management, 6(3), 1-7. Retrieved from http://www.researchjournali.com/view.php?id=4223

Gras-Gil, E., Marin-Hernandez, S., \& Garcia-Perez, L. D. (2012). Internal audit and financial reporting in the Spanish banking industry. Managerial Auditing Journal, 27(8), 728-753. https://doi.org/10.1108/02686901211257028

Gummesson, E. (2006). Qualitative research in management: addressing complexity, context and persona. Management Decision, 44(2), 167-179, https://doi.org/10.1108/00251740610650175

Harrison, T. M., \& Sayogo, D. S. (2014). Transparency, participation, and accountability practices in open government: A comparative study. Government Information Quarterly, 31(4), 513-525. Retrieved from https://doi.org/10.1016/j.giq.2014.08.002 
Ijeoma, N. B. (2014). The impact of international public sector accounting standard (IPSAS) on reliability, credibility and integrity of financial reporting in state government administration in Nigeria. International Journal of Technology Enhancements and Emerging Engineering Research, 2(3), 2347-4289. Retrieved from http://citeseerx.ist.psu.edu/viewdoc/summary?doi=10.1.1.428.7772

James, K. L. (2003). The effects of internal audit structure on perceived financial statement fraud prevention. Accounting Horizons, 17(4), 315-27. Retrieved from https://doi.org/10.2308/acch.2003.17.4.315

Jordaan, J. (2007). Contextualising the measurement of governance in public financial management. Retrieved from http://www.repository.up.ac.za/handle/2263/4455

Kamau, J. (2016). 24 county governments unable to account for Sh140 billion. Daily Nation. Available https://www.nation.co.ke/news/politics/twenty-four-county-governments-unable-account-billi ons/1064-3493232-9hcu5o/index.html

Kibet, P. (2017, Nov. 17). Audit General Edward Ouko reveals misuse of funds by county assemblies. The Standard. Available at https://www.standardmedia.co.ke/article/2001260442/audit-general-edward-ouko-reveals-mis use-of-funds-by-county-assemblies

Lessmann, C., \& Markwardt, G. (2010). One size fits all? Decentralisation, corruption, and the monitoring of bureaucrats. World Development, 38(4), 631-646. https://doi.org/10.1016/j.worlddev.2009.11.003

Liu, J., \& Lin, B. (2012). Government auditing and corruption control: Evidence from China's provincial panel data. China Journal of Accounting Research, 5(2), 163-186. Retrieved from https://www.sciencedirect.com/science/article/pii/S1755309112000172

Llewellyn, S. (1999). Narratives in accounting and management research, Accounting,

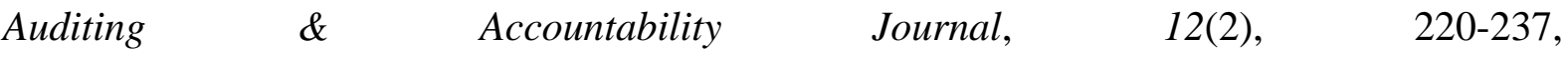
https://doi.org/10.1108/09513579910270129

McKenna, F. (2011). Auditors and audit reports: Is the firm's "John Hancock" enough? Forbes, July 11. Retrieved from http://goo.gl/Mra3Yq

Montesinos, V., Brusca, I., \& Go'mez-Villegas, M. (2016). Public financial management reforms: The role of IPSAS in Latin-America. Public Administration and Development, 36(1), 51-64 DOI 10.1002\%2Fpad.1747

Mwenda, A. K. (2010). Economic and administrative implications of the devolution framework established by the constitution of Kenya. Institute of Economic Affairs: Nairobi Retrieved from www.ieakenya.or.ke\%2Fdownloads.php\%3Fpage\%3DEconomic-and-Administrative-Implica tions-of-Devolution.pdf

Maina, R. W. (2016). The role of public financial management practices on service delivery 
in selected counties: perception of members of county assembly. Unpublished Msc Commerce Thesis, Kenya College of Accountancy University. Retrieved from http://41.89.49.13:8080/xmlui/handle/123456789/1170

Njoki, K. (2018, Sep 4). Kwale County given 7 days to submit county financial documents. Capital News. Retrieved from https://www.capitalfm.co.ke/news/2018/09/kwale-county-given-7-days-to-submit-county-fina ncial-documents/

OECD (2013). Global Forum on Transparency and Exchange of Information for Tax Purposes Global Forum on Transparency and Exchange of Information for Tax Purposes Peer Reviews. OECD Publishing. Available at http://www.un.org/esa/ffd/wp-content/uploads/sites/3/2017/05/Global-Forum_-info-sheet-201 7.pdf

Oluoch, F. O. (2018). Auditing of public sector entities. Presentation at ICPAK Audit Quality Assurance Workshop held on $7^{\text {th }}$ March, 2018 at the Waterbuck Hotel. Retrieved from https://www.icpak.com/wp-content/uploads/2018/03/CPA-Fred-Oluoch.pdf

Paulsson, G. (2006). Accrual accounting in the public sector: experiences from the central government in Sweden. Financial Accountability \& Management, 22(1), 47-62. https://doi.org/10.1111/j.0267-4424.2006.00392.x

Rotich, H. (2016). The Strategy for PFM Reforms in Kenya 2013-2018. Nairobi: National Treasury.

Ruppel, W. (2018). Financial Statements Prepared by Governments. https://doi.org/10.1002/9781119396253.ch9

Samani, N. (2015). The sheep watching the shepherd: The monitoring performance of the boards with employee representatives. Doctoral Thesis. School of Business Economics and Law, University of Gothenburg. Retrieved from https://gupea.ub.gu.se/bitstream/2077/37904/2/gupea_2077_37904_2.pdf

Scott, G. K. (2018). Accounting and Financial Reporting Practices as Tools for Service Delivery in The Public Service: The Case of Ghana's District Assemblies. Researchjournali's Journal of Accounting, 6(1), 1-16. Retrieved from https://www.researchjournali.com/view.php?id=4257

Senarath Y, P. W., \& Ukwatte, S. (2015). The New Public Financial Management (NPFM) and Accrual Accounting in Sri Lanka, in Jayasinghe, K., Nirmala D. N., Radiah O. (eds.). The Public Sector Accounting, Accountability and Auditing in Emerging Economies (pp.7 - 50). Emerald Group Publishing Limited.

Siswana, B. (2007). Leadership and Governance in the South African Public Service: An Overview of the Public Finance Management System. Doctoral Dissertation, University of Pretoria, South Africa. Retrieved from http://repository.up.ac.za/handle/2263/28035

The Financial Reporting Council. (2015). Enhancing Confidence in Audit: Proposed 


\section{Macrothink}

Journal of Public Administration and Governance ISSN 2161-7104 2018, Vol. 8, No. 4

Revisions to the Ethical Standard, Auditing Standards, UK Corporate Governance Code and Guidance on Audit Committees. The Financial Reporting Council Limited: London. Retrieved from https://www.frc.org.uk/document-library/audit-and-assurance/2015/impact-assessment-enhan cing-confidence-in-audit

Wang'ombe, J. M., \& Kibati, P. (2016). Analysis of financial management practices on effective use of public funds in the County Government of Nakuru, Kenya. International Journal of Economics, Commerce and Management, 4(4), 1197-1223. Available at http://ijecm.co.uk/wp-content/uploads/2016/04/4470.pdf

\section{Copyright Disclaimer}

Copyright for this article is retained by the author(s), with first publication rights granted to the journal.

This is an open-access article distributed under the terms and conditions of the Creative Commons Attribution license (http://creativecommons.org/licenses/by/4.0/). 